\title{
Geopolymer Mortar with the Tailings from the Fundão Dam Rupture
}

\author{
Glaucia Marcossi Cardoso Duarte, Fabiana Grasiele Penido Andrade Silva, \\ Fernando Soares Lameiras, Ana Maria Matildes dos Santos
}

Nuclear Technology Development Center-CDTN, National Nuclear Energy Commission, Belo Horizonte, Brazil

Email: glauciamduarte@gmail.com

How to cite this paper: Duarte, G. M. C., Silva, F. G. P. A., Lameiras, F. S., \& Santos, A. M. M. (2020). Geopolymer Mortar with the Tailings from the Fundão Dam Rupture. Technology and Investment, 11, 99-109. https://doi.org/10.4236/ti.2020.114006

Received: July 20, 2020

Accepted: August 29, 2020

Published: September 2, 2020

Copyright $\odot 2020$ by author(s) and Scientific Research Publishing Inc. This work is licensed under the Creative Commons Attribution International License (CC BY 4.0).

http://creativecommons.org/licenses/by/4.0/

\begin{abstract}
The extraction of iron ore generates large amounts of tailings. In addition to other solutions to avoid storing this material in dams, it is important to use these tailings as raw materials for the manufacturing of consumer goods. One possible solution is to use geopolymer cement in mortars for civil construction with employment of the tailings as substitute for usual sands. Geopolymers are produced from alkaline activation of aluminosilicates. They can incorporate a larger amount of tailings than the Portland cement. The tailings from the rupture of the Fundão dam, which were retained in the water reservoir of the Candonga hydropower plant were characterized as a fine aggregate for civil construction and used to obtain geopolymer mortar. Metakaolin was mixed with an alkaline solution of sodium silicate and sodium hydroxide to form a paste. The tailings were added and uniformly mixed to this paste. Two series of experiments were conducted with addition of 40 and $60 \mathrm{wt} \%$ of tailings to the geopolymer paste. The fresh mortars were placed in cylindrical molds. The samples were left to harden at room temperature or at $60^{\circ} \mathrm{C}$ for 24 hours and demolded. After hardening, the samples were cured at room temperature for 7 and 28 days. The samples were characterized by their compressive strength, water absorption, and density. The results were analyzed according to a $2^{3}$ factorial design with the factors: composition (amount of tailings added to the mortar), hardening conditions, and curing time. For all responses (compressive strength, water absorption, and density), the results show a complex behavior with influence of the factors and their interactions. Compressive strengths from 19 to $43 \mathrm{MPa}$, water absorptions from 19 to 41 $\mathrm{wt} \%$, and densities from 1.60 to $2.11 \mathrm{~g} / \mathrm{cm}^{3}$ were observed. These properties can be controlled by adjusting the levels of the factors according to empirical models. This mortar can be considered for applications in civil construction.
\end{abstract}

\section{Keywords}

Geopolymer, Candonga Tailings, Mortar 


\section{Introduction}

The collapse of the Fundão dam dispersed tailings from the Mariana region, in the state of Minas Gerais, as far as to the coast of the state of Espírito Santo in Brazil. These tailings resulted from the concentration of iron ore extracted from banded iron formations. Approximately 32 million $\mathrm{m}^{3}$ of tailings leaked from the Fundão dam and flowed down the Santarém creek, before reaching the rivers Gualaxo do Norte, Carmo, and Doce (Fundação Renova, 2017). Flora and fauna of the riverbanks and riverbed sediments were carried together with the tailings and reached the Risoleta Neves hydroelectric power plant (HPP), known as Candonga, where 10.5 million $\mathrm{m}^{3}$ were retained and deposited in the water reservoir.

The tailings in the Candonga water reservoir are a mixture of slime tailings generated in the desliming step and sandy tailings generated in the flotation step of the iron ore concentration process. It also contains parts of soil and organic matter. The return of operations in the HPP depends on the removal of these tailings, which are currently being dredged out and stored in an area adjacent to the plant. The use of these tailings as a raw material for the manufacture of consumer goods is being considered. Cement products for civil construction are interesting because there is local demand and the possibility of using large quantities of tailings. However, their use in Portland cement is limited due to the fine grain size of the tailings (Day, 2006).

Concretes made by our group with the Candonga tailings and Portland cement achieved compressive strengths at most $18 \mathrm{MPa}$, which is below the required value. The use of alkali-activated or geopolymer cements (Attanasio et al., 2018; Criado \& Provis, 2018; Rocha et al., 2018) is being considered because they have higher capacity to incorporate finely granulated aggregates. The objective of this study was to explore the possibility of producing geopolymer mortars using tailings dredged from the Candonga water reservoir.

\section{Materials and Methods}

Commercial kaolin (Sulfal, of technical degree) was calcined at $800^{\circ} \mathrm{C}$ for 4 hours in a muffle oven. The heating rate was $10^{\circ} \mathrm{C} / \mathrm{min}$. After the calcination program was completed, the oven was allowed to cool naturally. Fourier transform infrared spectroscopy (FTIR) and X-ray diffractometry (DRX) analyses showed that metakaolin was obtained. The metakaolin was also characterized by laser scattering granulometry and specific surface by BET method.

Technical grade sodium hydroxide flakes were used to prepare a $10 \mathrm{~mol} \cdot \mathrm{L}^{-1}$ solution with tap water, which was supplied by the local water company (COPASA). Alkaline sodium silicate was purchased from GETEX (46 wt\% of solids, $\mathrm{Si} / \mathrm{Na}$ of 2.2).

The tailings were collected from the pile where they have been stored after dredging. The collection took place as follows: for every 100 meters of the tailings pile, two $50 \mathrm{~kg}$ portions were collected at different depths in the pile, totaling $500 \mathrm{~kg}$ of material, which was homogenized. From this amount, a $5 \mathrm{~kg} \mathrm{sam}$ - 
ple was taken for this study. The sample of tailings was dried at $105^{\circ} \mathrm{C}$ for 24 hours and sieved to remove stones, dry branches, leaves and other materials that could hinder the mixing process during the preparation of the mortar. The tailings were characterized by laser scattering granulometry, powdered material content, clay content in clods, real specific mass, water absorption, humidity, unit mass, swelling, organic matter content, X-rays fluorescence (FRX), DRX, FTIR, and scanning electron microscopy (SEM).

The sodium hydroxide solution and the alkaline sodium silicate were mixed to obtain the activation solution. Metakaolin was mixed with the activation solution in such a proportion as to give a $\mathrm{Si} / \mathrm{Al}$ ratio in the geopolymer of around 1.55. The $\mathrm{Na} / \mathrm{Al}$ was around 1.17. The mixing was performed manually with a spatula until achieving a uniform paste. Afterwards, the tailings were added to the paste and mixed up to produce a uniform fresh mortar. The fresh mortar was set in cylindrical molds ( $5 \mathrm{~cm}$ of diameter, $10 \mathrm{~cm}$ of height) and then stirred for 10 minutes in an orbital stirrer to remove air bubbles. Water had to be added during the addition of $60 \mathrm{wt} \%$ of tailings to improve the workability of the fresh mortar. The hardening was performed at room conditions and at $60^{\circ} \mathrm{C}$ in an oven, for 24 hours in both cases. After hardening, the samples were demolded and cured for 7 and 28 days at room conditions.

A $2^{3}$ factorial design was performed as shown in Table 1 . The responses were the compressive strength, geometric density, and water absorption of the cured samples. Three samples of each combination of the factors were characterized. The compressive strength was measured according to the norm ABNT NBR 7215. The water absorption was measured according to the norm ABNT NBR 9778. The geometric density was calculated by weighing the samples after drying according to the norm ABNT NBR 9778.

\section{Results}

Metakaolin formation after the calcination of kaolinite could be confirmed by XRD and FTIR, revealing the loss of hydroxyl groups and an amorphous character. Table 2 and Table 3 show the results of the characterization of the tailings.

Figure 1 shows an SEM image of the tailings. Particles of quartz can be seen with a number of small particles adhered to their surfaces, some of them have a lamellar shape (probably clay particles). Table 3 shows indeed a high content of clay in the tailings. These small particles explain the high content of pulverulent

Table 1. $2^{3}$ factorial design for the geopolymer samples with the tailings from Candonga.

\begin{tabular}{ccc}
\hline Factor & Low level, code: -1 & High level, code: +1 \\
\hline Tailing content & $40 \mathrm{wt} \%$ & $60 \mathrm{wt} \%$ \\
Hardening & Room conditions, 24 hours & $60^{\circ} \mathrm{C}, 24$ hours \\
Curing & Room conditions, 7 days & Room conditions, 28 days \\
\hline
\end{tabular}


Table 2. Results of the Candonga tailings from XRD and XRF.

\begin{tabular}{cccc}
\hline & XRD & \multicolumn{2}{c}{ FRX } \\
\hline Mineral & wt\% & Element & wt\% \\
\hline Quartz & 79 & $\mathrm{SiO}_{2}$ & 70.9 \\
Hematite & 9 & $\mathrm{Fe}_{2} \mathrm{O}_{3}$ & 14.6 \\
Clays & 5 & $\mathrm{Al}_{2} \mathrm{O}_{3}$ & 11.3 \\
Others & 7 & Others & 3.2 \\
\hline
\end{tabular}

Table 3. Results of the Candonga tailings characterization compared with natural sands.

\begin{tabular}{ccccc}
\hline & Pulverulent material & Clay & Specific Mass & Water absorption \\
\hline Candonga tailing & $28 \mathrm{wt} \%$ & $5-11 \mathrm{wt} \%$ & $2781.54 \mathrm{~kg} / \mathrm{m}^{3}$ & $0.71 \mathrm{wt} \%$ \\
Natural sands & $\sim 1 \mathrm{wt} \%$ & no $-1 \mathrm{wt} \%$ & $\sim 2620 \mathrm{~kg} / \mathrm{m}^{3}$ & $\sim 1.2 \mathrm{wt} \%$ \\
& Humidity & Unit mass & Swelling & Organic matter* \\
Candonga tailing & $1.76 \mathrm{wt} \%$ & $1656.95 \mathrm{~kg} / \mathrm{m}^{3}$ & 1.192 & Yes \\
Natural sand & $\sim 2 \mathrm{wt} \%$ & $1300-1750 \mathrm{~kg} / \mathrm{m}^{3}$ & $\sim 1.6$ & No \\
\hline
\end{tabular}

${ }^{*}$ According to the norm ABNT Mercosul NM 49:2001.

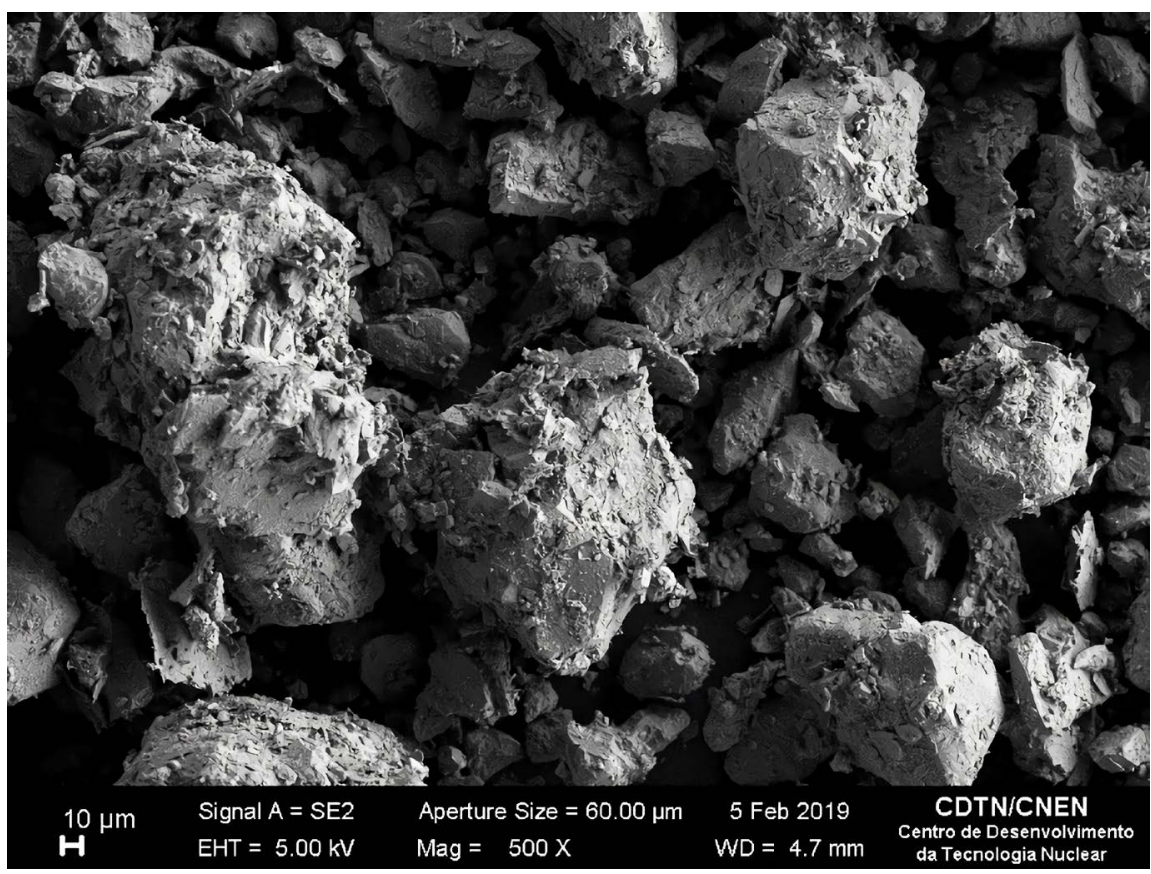

Figure 1. SEM image of the tailings from the Candonga water reservoir.

material, as shown in Table 3 . The composition of the pulverulent material measured by $\mathrm{FRX}$ is $\mathrm{SiO}_{2}$ (81.0 wt\%), $\mathrm{Fe}_{2} \mathrm{O}_{3}$ (11.3 wt\%), $\mathrm{Al}_{2} \mathrm{O}_{3}$ (5.5 wt\%) and others (2.3 wt\%).

The tailings have a continuous particle size distribution, ideal to satisfy the granulometry requirement of the norm ABNT NBR 7211. Continuous particle size distribution means less voids and consequently less cement paste consump- 
tion in the mortar. The average particle diameter is $69.35 \mu \mathrm{m}$, with $10 \%$ of the particles having a diameter below $7.67 \mu \mathrm{m}, 50 \%$ below $59.60 \mu \mathrm{m}$ and $90 \%$ below $145.80 \mu \mathrm{m}$. The specific mass of $2781.54 \mathrm{~kg} / \mathrm{m}^{3}$ classifies the aggregate as heavy, and is due to the presence of minerals such as iron oxide. The water absorption of the tailings is $0.71 \mathrm{wt} \%$, less than that of natural sands ( 1.2 wt\%). The humidity of aggregate is related to the variation of water in the mortar and its swelling. The value of $1.76 \mathrm{wt} \%$ is low and suitable for use in mortars. The unit mass of $1656.95 \mathrm{~kg} / \mathrm{m}^{3}$ is in the expected range for natural sands (1300 to $1750 \mathrm{~kg} / \mathrm{m}^{3}$ ). The swelling of the tailings (1.192) is low compared to natural sands ( 1.6). Organic matter could be identified in the tailings.

Table 4 shows the results of the runs of the $2^{3}$ factorial design of Table 1 . The runs were performed in a random order.

According to Zhang et al. (2018), the compressive strength of different geopolymer mortars is between 7 and $50 \mathrm{MPa}$ in agreement with most of the results shown in Table 4. The reported water absorption values were below $16 \mathrm{wt} \%$. The values in Table 4 are higher, probably related to a high porosity of the samples.

The isolated effect of the factors and their interactions for the compressive strength, calculated with the software Minitab, are shown in Table 5. Only the interaction Composition ${ }^{\star}$ Curing is not significant. This is indicative of the complexity of geopolymer reactions and that the properties of the tailings influence these reactions. Table 6 shows the contribution of the main factors and the interactions calculated by the empirical model of Equation (1). According to Table 5 , the influence of the composition is negative, meaning that an increase in the tailings content decreases the compressive strength. This fact is expected due to the lower ratio of geopolymer binder to tailings. The effect of hardening is negative, revealing that the hardening at $60^{\circ} \mathrm{C}$ produced in average lower compressive strengths than the hardening at room temperature. This is an unexpected result, because the literature reports that the hardening at $60^{\circ} \mathrm{C}$ produces higher compressive strengths than the hardening at ambient temperature (Hameed et al., 2017).

Table 4. Results of the runs of the $2^{3}$ factorial design for the responses "Compressive strength", "Water absorption" and "Density" for samples of geopolymer mortars with the tailings from the Candonga water reservoir.

\begin{tabular}{ccccccccccccc}
\hline Tailing content Hardening & Curing & \multicolumn{2}{c}{ Compressive strength (MPa) } & \multicolumn{2}{c}{ Water absorption $(w t \%)$} & \multicolumn{3}{c}{ Density $\left(\mathrm{g} / \mathrm{cm}^{3}\right)$} \\
\hline-1 & -1 & -1 & 35.87 & 41.09 & 43.09 & 37.18 & 40.76 & 39.51 & 1.60 & 1.60 & 1.58 \\
+1 & -1 & -1 & 19.17 & 23.93 & 19.48 & 20.10 & 19.54 & 20.09 & 2.11 & 1.98 & 2.01 \\
-1 & +1 & -1 & 18.01 & 11.64 & 18.12 & 22.75 & 23.11 & 23.19 & 1.88 & 1.89 & 1.85 \\
+1 & +1 & -1 & 10.86 & 14.08 & 13.69 & 21.23 & 20.56 & 21.43 & 1.92 & 1.94 & 1.98 \\
-1 & -1 & +1 & 36.68 & 32.82 & 33.39 & 20.00 & 19.90 & 21.15 & 1.81 & 1.87 & 1.84 \\
+1 & -1 & +1 & 25.13 & 21.21 & 21.61 & 19.27 & 19.18 & 19.91 & 1.83 & 1.98 & 1.86 \\
-1 & +1 & +1 & 44.24 & 38.04 & 31.54 & 22.75 & 22.82 & 22.71 & 1.80 & 1.82 & 1.84 \\
+1 & +1 & +1 & 21.21 & 20.49 & 25.36 & 21.05 & 20.47 & 20.50 & 1.89 & 1.98 & 1.83 \\
\hline
\end{tabular}


Table 5. Effects of factors and their interactions for the compressive strength $\left(\mathrm{R}^{2}=\right.$ $92.11 \%, \mathrm{R}_{\text {adj }}^{2}=88.66 \%$ and $\left.\mathrm{R}_{\text {pred }}^{2}=82.25 \%\right)$.

\begin{tabular}{ccccc}
\hline Term & Effect & Coefficient & SE $_{\text {coef }}$ & p-value \\
\hline Constant & $* * * * *$ & 25.87 & & 0.000 \\
Composition & -12.36 & -6.18 & & 0.000 \\
Hardening & -7.18 & -3.59 & & 0.000 \\
Curing & 6.89 & 3.45 & 0.70 & 0.000 \\
Composition $\times$ Hardening & 3.04 & 1.52 & & 0.045 \\
Composition $\times$ Curing & -1.26 & -0.63 & & 0.382 \\
Hardening $\times$ Curing & 8.86 & 4.43 & & 0.000 \\
Composition $\times$ Hardening $\times$ Curing & -5.01 & -2.51 & & 0.003 \\
\hline
\end{tabular}

Table 6. Contribution of the main factors and interactions for the compressive strength calculated by the model of Equation (1).

\begin{tabular}{cccccc}
\hline Composition & Hardening & Curing & Main factors $(\mathrm{MPa})$ & Interactions $(\mathrm{MPa})$ & Model $(\mathrm{MPa})^{*}$ \\
\hline-1 & -1 & -1 & 32.19 & 7.83 & 40.02 \\
+1 & -1 & -1 & 19.83 & 1.03 & 20.86 \\
-1 & +1 & -1 & 25.01 & -9.09 & 15.92 \\
+1 & +1 & -1 & 12.65 & 0.23 & 12.88 \\
-1 & -1 & +1 & 39.09 & -4.79 & 34.30 \\
+1 & -1 & +1 & 26.73 & -4.07 & 22.66 \\
-1 & +1 & +1 & 31.91 & 6.05 & 37.96 \\
+1 & +1 & +1 & 19.55 & 2.81 & 22.36 \\
\hline
\end{tabular}

The effect of curing is positive, as expected and reported in the literature (Hameed et al., 2017). The contribution of the interactions can be synergic or antagonistic, depending on the combinations of the levels of the main factors. García-Mejía and Chávez-García (2016) studied the influence of the factors $\mathrm{KOH}$ concentration, temperature, time, and relative humidity of the hardening on the compressive strength of geopolymer using a factorial design. Interactions between the factors were observed. Krishnan and Purushothman (2017) also studied the influence of the molarity of the sodium hydroxide solution, time and temperature of hardening, and the content of recycled coarse aggregate on the compressive strength of geopolymer concrete using a factorial design. They observed an interaction between the time and temperature of hardening.

Compressive strength $(\mathrm{MPa})=25.87-6.18 \times$ Composition -3.59

$$
\begin{aligned}
& \times \text { Hardening }+3.45 \times \text { Curing }+1.52 \times \text { Composition } \\
& \times \text { Hardening }-0.63 \times \text { Composition } \times \text { Curing }+4.43(1) \\
& \times \text { Hardening } \times \text { Curing }-2.51 \times \text { Composition } \\
& \times \text { Hardening } \times \text { Curing }
\end{aligned}
$$


Figure 2 shows the response surfaces for the compressive strength. The surfaces are different for each hardening condition. The hardening at room temperature produced high compressive strengths after 7 days of curing. The hardening at $60^{\circ} \mathrm{C}$ produced lower strengths for 7 days of curing however, for 28 days of curing, the strengths increase considerably, especially for $40 \mathrm{wt} \%$ of tailings. Maybe the high content of organic matter in the tailings could be related to this unexpected behavior. Figure 2 also shows that the increase in the tailings content causes a decrease in the compressive strength.

Table 7 shows the effect of the factors and their interactions for the water absorption calculated with Minitab. All effects and interactions are significant. Table 8 shows the contribution of the main factors and the interactions calculated by the empirical model of Equation (2). The contribution of the interactions can also be synergic or antagonistic, depending on the combinations of the levels of the main factors.

$$
\begin{aligned}
\text { Water absorption }(\mathrm{wt} \%)= & 23.30-3.02 \times \text { Composition }-1.42 \times \text { Hardening } \\
& -2.49 \times \text { Curing }+2.01 \times \text { Composition } \times \text { Hardening } \\
& +2.38 \times \text { Composition } \times \text { Curing }+2.33 \times \text { Hardening } \\
& \times \text { Curing }-2.31 \times \text { Composition } \times \text { Hardening } \times \text { Curing }
\end{aligned}
$$

Figure 3 shows the response surface for water absorption. It is lower for the hardening at $60^{\circ} \mathrm{C}$. For the hardening at room temperature it falls considerably with the increase of the tailings content and the time of curing. This behavior is also unexpected, because the water absorption is related to the volume of open porosity, which is expected to increase with the tailings content. A possible explanation could be the contribution of the geopolymer binder to the water absorption, which is high for the hardening at room temperature and low for the hardening at $60^{\circ} \mathrm{C}$.

Table 9 shows the effect of the factors and interactions for the density calculated with Minitab. Only the effect of curing is not significant. Table 10 shows

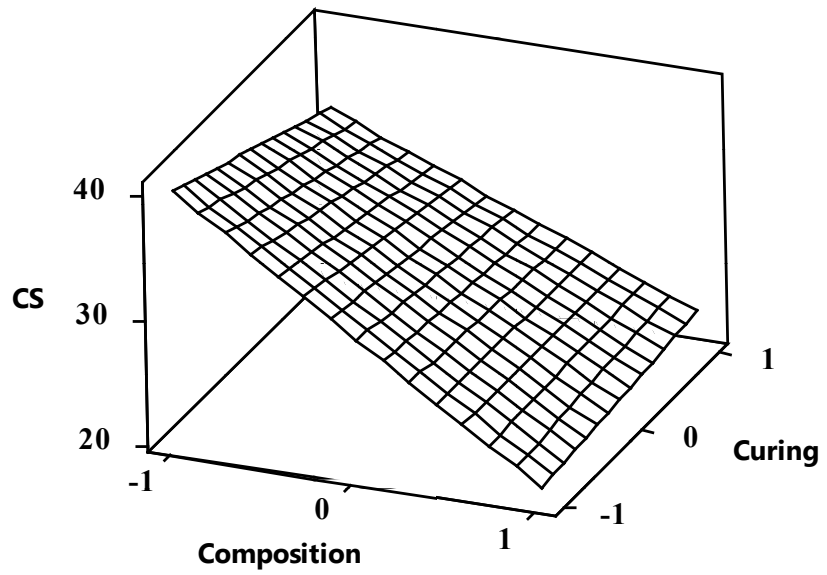

Hardening at room temperature, $24 \mathrm{~h}$

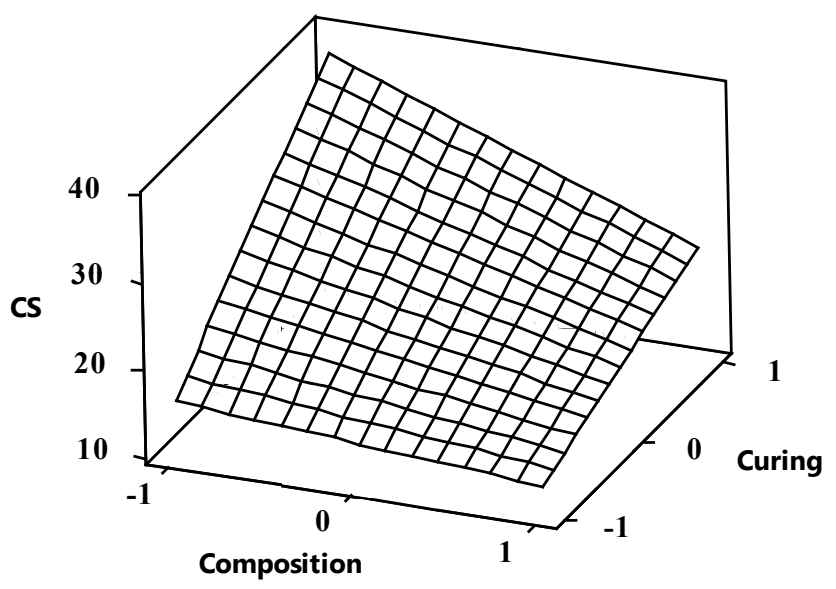

Hardening at $60^{\circ} \mathrm{C}, 24 \mathrm{~h}$

Figure 2. Response surface of the compressive strength (CS, MPa) of geopolymer mortar with the addition of $40 \mathrm{wt} \%(-1)$ and $60 \mathrm{wt} \%(+1)$ of tailings for 7 days $(-1)$ and 28 days $(+1)$ of curing and hardening at room temperature and at $60^{\circ} \mathrm{C}$. 
Table 7. Effects and their interactions for the water absorption $\left(R^{2}=99.02 \%, R_{\text {adj }}^{2}=\right.$ $98.60 \%$ and $\left.\mathrm{R}_{\text {pred }}^{2}=97.80 \%\right)$.

\begin{tabular}{ccccc}
\hline Term & Effect & Coefficient & SE $_{\text {coef }}$ & p-value \\
\hline Constant & $* * * * *$ & 23.30 & & 0.000 \\
Composition & -6.04 & -3.02 & & 0.000 \\
Hardening & -2.84 & -1.42 & & 0.000 \\
Curing & -4.98 & -2.49 & 0.15 & 0.000 \\
Composition $\times$ Hardening & 4.03 & 2.01 & & 0.000 \\
Composition $\times$ Curing & 4.55 & 2.28 & & 0.000 \\
Hardening $\times$ Curing & 4.65 & 2.33 & & 0.000 \\
Composition $\times$ Hardening $\times$ Curing & -4.62 & -2.31 & & 0.000 \\
\hline
\end{tabular}

Table 8. Contribution of the main factors and interactions for water absorption calculated by the model of Equation (2).

\begin{tabular}{cccccc}
\hline Composition & Hardening & Curing & Principal (wt\%) & Interactions (wt\%) & Model (wt\%) \\
\hline-1 & -1 & -1 & 30.23 & 8.93 & 39.16 \\
+1 & -1 & -1 & 24.19 & -4.27 & 19.92 \\
-1 & +1 & -1 & 27.39 & -4.37 & 23.02 \\
+1 & +1 & -1 & 21.35 & -0.29 & 21.06 \\
-1 & -1 & +1 & 25.25 & -4.91 & 20.34 \\
+1 & -1 & +1 & 19.21 & 0.25 & 19.46 \\
-1 & +1 & +1 & 22.41 & 0.35 & 22.76 \\
+1 & +1 & +1 & 16.37 & 4.31 & 20.68 \\
\hline
\end{tabular}

Table 9. Effects and their interactions for the density calculated with Minitab $\left(\mathrm{R}^{2}=\right.$ $89.74 \%, \quad \mathrm{R}_{\text {adj }}^{2}=85.25 \%$ and $\mathrm{R}_{\text {pred }}^{2}=76.91 \%$ ).

\begin{tabular}{ccccc}
\hline Term & Effect & Coefficient & SE $_{\text {coef }}$ & p-value \\
\hline Constant & $* * * *$ & 1.86 & & 0.000 \\
Composition & 0.16 & 0.08 & & 0.000 \\
Hardening & 0.05 & 0.02 & & 0.037 \\
Curing & 0,00 & 0,00 & 0.01 & 0.967 \\
Composition $\times$ Hardening & -0.08 & -0.04 & & 0.001 \\
Composition $\times$ Curing & -0.10 & -0.05 & & 0.000 \\
Hardening $\times$ Curing & -0.05 & -0.03 & & 0.022 \\
Composition $\times$ Hardening $\times$ Curing & 0.10 & 0.05 & & 0.000 \\
\hline
\end{tabular}

the contribution of the main factors and the interactions calculated by the empirical model of Equation (3). The contribution of the interactions can also be synergic or antagonistic, depending on the combinations of the levels of the main factors. 


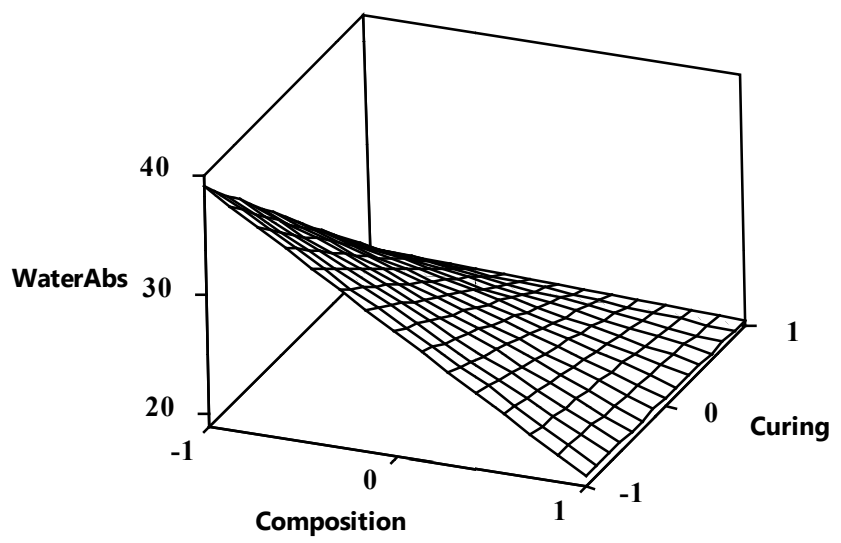

Hardening at room temperature, $24 \mathrm{~h}$

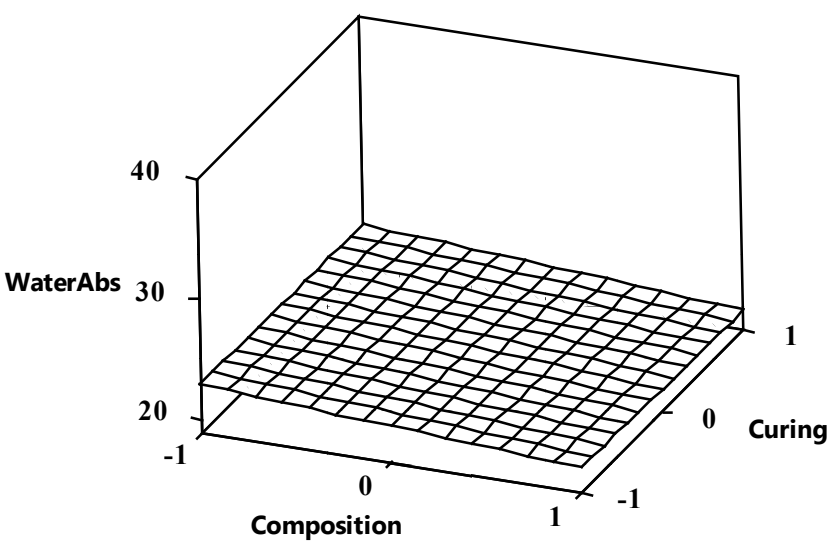

Hardening at $60^{\circ} \mathrm{C}, 24 \mathrm{~h}$

Figure 3. Response surface of the water absorption (in wt\%) of geopolymer mortar with the addition of $40 \mathrm{wt} \%(-1)$ and $60 \mathrm{wt} \%$ $(-1)$ of tailings for 7 days $(-1)$ and 28 days $(+1)$ of curing and hardening at room temperature and at $60^{\circ} \mathrm{C}$.

Table 10. Effects and their interactions for the density calculated with Minitab $\left(\mathrm{R}^{2}=\right.$ $89.74 \%, \mathrm{R}_{\text {adj }}^{2}=85.25 \%$ and $\left.\mathrm{R}_{\text {pred }}^{2}=76.91 \%\right)$.

\begin{tabular}{cccccc}
\hline Composition & Hardening & Curing & Principal $\left(\mathrm{g} / \mathrm{cm}^{3}\right)$ & Interactions $\left(\mathrm{g} / \mathrm{cm}^{3}\right)$ & Model $\left(\mathrm{g} / \mathrm{cm}^{3}\right)$ \\
\hline-1 & -1 & -1 & 1.76 & -0.17 & 1.59 \\
+1 & -1 & -1 & 1.92 & 0.11 & 2.03 \\
-1 & +1 & -1 & 1.80 & 0.07 & 1.87 \\
+1 & +1 & -1 & 1.96 & -0.01 & 1.95 \\
-1 & -1 & +1 & 1.76 & 0.09 & 1.85 \\
+1 & -1 & +1 & 1.92 & -0.03 & 1.89 \\
-1 & +1 & +1 & 1.80 & 0.01 & 1.81 \\
+1 & +1 & +1 & 1.96 & -0.07 & 1.89 \\
\hline
\end{tabular}

$$
\begin{aligned}
\operatorname{Density}\left(\mathrm{g} / \mathrm{cm}^{3}\right)= & 1.86+0.08 \times \text { Composition }+0.02 \times \text { Hardening } \\
& +0.00 \times \text { Curing }-0.04 \times \text { Composition } \times \text { Hardening } \\
& -0.05 \times \text { Composition } \times \text { Curing }-0.03 \times \text { Hardening } \\
& \times \text { Curing }+0.05 \times \text { Composition } \times \text { Hardening } \times \text { Curing }
\end{aligned}
$$

Figure 4 shows the response surface for density. There is little variation for the hardening at $60^{\circ} \mathrm{C}$ for the combinations of composition and curing studied. For the hardening at room temperature, it decreases considerably with the decrease of the tailings content. The time of curing has a negligible influence on the density in both cases of curing.

Table 11 shows the results for compressive strength obtained for 14 days of curing for combinations of composition and hardening and the values calculated by the empirical model of Equation (1). The empirical model underestimates most of the values, suggesting that the response surfaces of Figure 1 should be slightly curved towards higher values. 


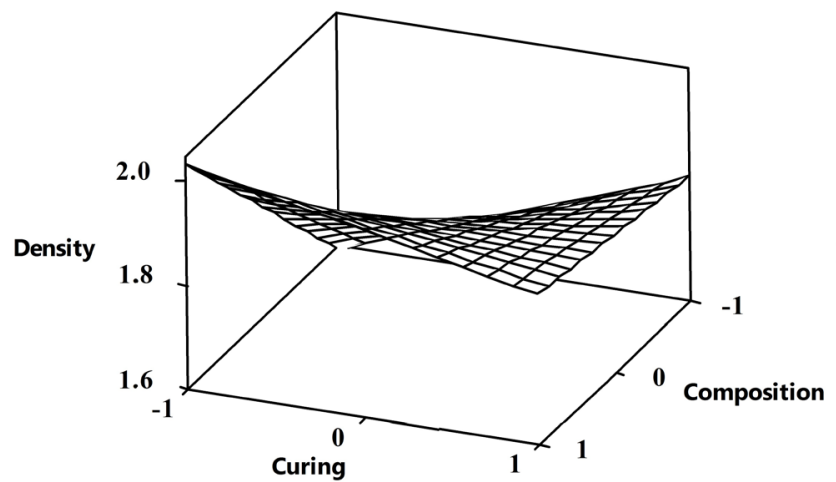

Hardening at room temperature, $24 \mathrm{~h}$

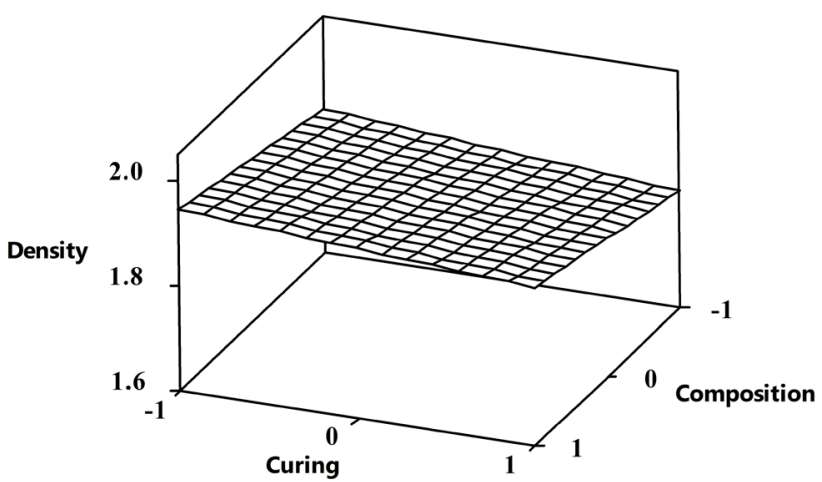

Hardening at $60^{\circ} \mathrm{C}, 24 \mathrm{~h}$

Figure 4. Response surface of the density of geopolymer mortar with the addition of $40 \mathrm{wt} \%(-1)$ and $60 \mathrm{wt} \%(-1)$ of tailings for 7 days $(-1)$ and 28 days $(+1)$ of curing and hardening at room temperature and at $60^{\circ} \mathrm{C}$ (these surfaces are rotated in relation to the ones of Figure 2 and Figure 3 for better visualization).

Table 11. Comparison of measure of compressive strength for 14 days (level $=0.5$ ) of curing with the prediction of the empirical model of Equation (1).

\begin{tabular}{cccccccc}
\hline Composition & Hardening & Curing & & Measures & & Mean & Model \\
\hline-1 & -1 & & 36.76 & 43.25 & 40.13 & 40.05 & 38.24 \\
+1 & -1 & & 28.18 & 27.65 & 26.76 & 27.50 & 19.70 \\
-1 & +1 & 0.5 & 36.73 & 30.21 & 33.55 & 33.55 & 31.20 \\
+1 & +1 & & 20.64 & 20.01 & 18.76 & 19.80 & 19.99 \\
\hline
\end{tabular}

\section{Conclusion}

Geopolymer mortars were obtained with addition of $40 \mathrm{wt} \%$ and $60 \mathrm{wt} \%$ of the tailings deposited in the Candonga water reservoir because of the Fundão Dam rupture. The geopolymer paste was synthetized with metakaolin, sodium silicate, and $10 \mathrm{M}$ sodium hydroxide solution. The tailings were dried and sieved to remove stones, dry branches, leaves and other materials that could hinder the mixing process during mortar synthesis. The hardening of the mortar samples was performed at room conditions or at $60^{\circ} \mathrm{C}$ for 24 hours. Samples of mortars with curing times of 7 and 28 days at room conditions were characterized. The compressive strength, water absorption, and density of mortar samples showed complex behavior with influence of tailings content, hardening conditions, and curing time, as well as the interactions of these factors, which can be synergic or antagonistic, depending on their combination. In addition, the influence of some factors was unexpected when compared to the results reported in the literature, probably due to the composition of the tailings. Compressive strengths from 19 to $43 \mathrm{MPa}$, water absorptions from 19 to $41 \mathrm{wt} \%$, and densities from 1.60 to $2.11 \mathrm{~g} / \mathrm{cm}^{3}$ were observed for different mortar synthesis conditions. These properties can be controlled by adjusting the level of the factors according to empirical models. These mortars can be considered for applications in civil construction. 


\section{Acknowledgements}

The authors would like to thank the support of FAPEMIG (Rede Candonga), CAPES, CNPq, Fundação Renova, and the City of Rio Doce (Minas Gerais, Brazil).

\section{Conflicts of Interest}

The authors declare no conflicts of interest regarding the publication of this paper.

\section{References}

Attanasio, A., Pascali, L., Tarantino, V., Arena, W., \& Largo, A. (2018). Alkali-Activated Mortars for Sustainable Building Solutions: Effect of Binder Composition on Technical Performance. Environments, 5, 35. https://doi.org/10.3390/environments5030035

Criado, M., \& Provis, J. L. (2018). Alkali-Activated Slag Mortars Provide High Resistance to Chloride-Induced Corrosion of Steel. Frontiers in Materials, 5, 34. https://doi.org/10.3389/fmats.2018.00034

Day, K. W. (2006). Concrete Mix Design, Quality Control and Specification (3rd ed.). New York: Taylor \& Francis.

Fundação Renova (2017). Presentation of the TTAC Agreement and Recovery Actions of the Impacted Areas and Communities. (Available in Portuguese) https://www.fundacaorenova.org/wp-content/uploads/2016/12/o-termo-e-os-41-progr amas.pdf

García-Mejía, T. A., \& Chávez-García, M. L. (2016). Compressive Strength of Metakaolin-Based Geopolymers: Influence of $\mathrm{KOH}$ Concentration, Temperature, Time and Relative Humidity. Materials Sciences and Applications, 7, 772-791. https://doi.org/10.4236/msa.2016.711060

Hameed, A. M., Rawdan, R. R., \& Mishhadani, S. A. (2017). Effect of Various Factors on the Manufacturing of Geopolymer Mortar. Archives of Science, 1, Article ID: 1000111.

Krishnan, T., \& Purushothman, R. (2017). Optimization and Influence of Parameter Affecting the Compressive Strength of Geopolymer Concrete Containing Recycled Concrete Aggregate: Using Full Factorial Design Approach. IOP Conference Series: Earth and Environmental Science, 80, Article ID: 012013. https://doi.org/10.1088/1755-1315/80/1/012013

Rocha, T. S., Dias, D. P., França, F. C. C., Guerra, R. R. S., \& Marques, L. R. C. O. (2018). Metakaolin-Based Geopolymer Mortars with Different Alkaline Activators $\left(\mathrm{Na}^{+}, \mathrm{K}^{+}\right)$. Construction and Building Materials, 178, 453-461. https://doi.org/10.1016/j.conbuildmat.2018.05.172

Zhang, P., Zhang, Y., Wang, K., \& Zhang, J. (2018). A Review on Properties of Fresh and Hardened Geopolymer Mortar. Composites Part B: Engineering, 152, 79-95.

https://doi.org/10.1016/j.compositesb.2018.06.031 